\title{
A USP53 p.Cys228Arg variant is associated with autosomal recessive psychosis
}

José V Pardo ${ }^{1,2}$, Sohail A Sheikh ${ }^{3}$, Faiza Aslam ${ }^{4}$, Samina Yasin ${ }^{4}$, Ambreen Kanwal ${ }^{4}$, and Sadaf Naz ${ }^{4,5,6}$

${ }^{1}$ Department of Psychiatry, Cognitive Neuroimaging Unit, Minneapolis Veterans Health Care System

${ }^{2}$ University of Minnesota

${ }^{3}$ Hawkes Bay Hospital

${ }^{4}$ School of Biological Sciences, University of the Punjab

${ }^{5}$ School of Biological Sciences, Correspondence to José V. Pardo, VAMC

${ }^{6}$ University of the Punjab

July 14, 2021

\section{Hosted file}

Pardo Authorea v2.pdf available at https://authorea.com/users/425229/articles/530110-a-usp53p-cys228arg-variant-is-associated-with-autosomal-recessive-psychosis 